\title{
Wpływ warunków zgrzewania FSW na proces tworzenia złącza z materiałów różniących się właściwościami fizycznymi
}

\author{
Influence of the FSW conditions on the formation \\ process of weld made from materials of different \\ physical properties
}

\section{Streszczenie}

W artykule przedstawiono wyniki badań procesu zgrzewania FSW trudno spajanego znanymi technikami spawalniczymi zestawu materiałów: aluminium odlewniczego z aluminium przerabianym plastycznie. Przedstawiono badania procesu uplastyczniania aluminium oraz formowania się zgrzeiny liniowej w różnych warunkach prowadzenia procesu zgrzewania. Badano wpływ kształtu części roboczych narzędzia, parametrów procesu zgrzewania oraz oprzyrządowania zgrzewalniczego na strukturę zgrzein oraz na stabilność i jakość zgrzewania. Analizowano proces zgrzewania realizowany za pomocą narzędzi konwencjonalnych, stożkowych oraz typu Triflute.

W wyniku badań powiązano warunki zgrzewania FSW aluminiowych stopów odlewniczych ze stopami przerabianymi plastycznie z jakością uzyskanych zgrzein. Zastosowanie metody zgrzewania FSW przedstawiono na przykładzie łączenia elementów wymienników ciepła.
Abstract

Results of FSW of set of materials: cast aluminium alloy with wrought aluminium alloy, hard to weld with the conventional fusion welding techniques, are presented in this paper. Investigation of the plasticization process of aluminium and the formation process of linear weld in the different welding conditions are also presented. Influence of the tools' shape, welding parameters and the tooling on the welds' structure and on the stability and quality of welding were studied. FSW process using conventional, conical and Triflute tools was analysed.

As a result of investigation, FSW welding conditions of cast aluminium alloys with wrought aluminium alloy were connected with quality of welds. Application of the FSW method was exemplified as joining of radiators' elements.

\section{Wstęp}

Proces zgrzewania FSW jest stosunkowo prosty do realizacji w przypadku łączenia elementów wykonanych $z$ takich samych materiałów lub materiałów nieznacznie różniących się właściwościami fizycznymi $[1,2]$. W przypadku łączenia materiałów różnorodnych, zwłaszcza różniących się właściwościami fizycznymi, znacznie trudniej uzyskać odpowiednią jakość złącza

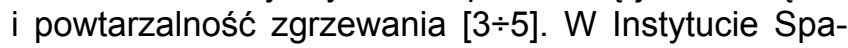
walnictwa podjęto pracę $\mathrm{w}$ zakresie łączenia elemen-

Dr inż. Adam Pietras, mgr inż. Aleksandra Węglowska, mgr inż. Damian Miara - Instytut Spawalnictwa, Gliwice. tów wykonanych $z$ odlewniczego stopu aluminium $z$ elementami wykonanymi $z$ aluminium przerabianego plastycznie.

W pierwszym etapie pracy badano proces uplastyczniania materiału $w$ obszarze styku podczas procesu zgrzewania FSW próbek wykonanych z odlewniczego stopu aluminium i aluminium przerabianego plastycznie oraz proces formowania się zgrzeiny liniowej w różnych warunkach prowadzenia procesu. Sprawdzono wpływ kształtu i wymiarów narzędzia oraz parametrów jego ruchu na proces formowania się poprawnej zgrzeiny liniowej.

W dalszej kolejności przeprowadzono próby i badania procesu zgrzewania modelowej chłodnicy, której 
korpus wykonano z odlewanego stopu aluminium, natomiast pokrywę z aluminium przerabianego plastycznie.

W artykule przedstawiono wybrane wyniki badań dotyczących procesu zgrzewania FSW odlewniczego stopu aluminium EN AC-43200 oraz stopu EN AW-2017A.

\section{Stanowisko badawcze}

Badania procesu FSW podczas zgrzewania elementów wykonanych $\mathrm{z}$ aluminium odlewniczego z elementami wykonanymi z aluminium przerabianym plastycznie przeprowadzono na stanowisku badawczym składającym się z frezarki pionowej FYF32JU2, wyposażonej w specjalne oprzyrządowanie. Do prowadzenia badań stanowisko badawcze wyposażono w uchwyty mocujące zgrzewane płyty oraz różne przyrządy do rejestracji warunków zgrzewania. Na rysunku 1 przedstawiono widok stanowiska badawczego do badań procesu zgrzewania liniowego płyt. $\mathrm{Na}$ stanowisku tym prowadzono proces zgrzewania elementów modelowej chłodnicy.

Badania sił i momentu siły podczas procesu zgrzewania FSW realizowano na stanowisku wyposażonym dodatkowo w przyrząd Lowstir do pomiaru i rejestracji parametrów mechanicznych procesu zgrzewania. Stanowisko badawcze z założoną głowicą Lowstir na wrzecionie zgrzewarki przedstawiono na rysunku 1b. Dane rejestrowane przez głowicę pomiarową Lowstir były gromadzone w pamięci komputera i następnie przetwarzane za pomocą specjalistycznego oprogramowania.

\section{Materiały do badań}

Do badań zgrzewania metodą FSW elementów chłodnic wykonanych ze stopu odlewniczego i stopu przerabianego plastycznie stosowano próbki wyfrezowane z materiału odlewniczego EN AC-43200 oraz
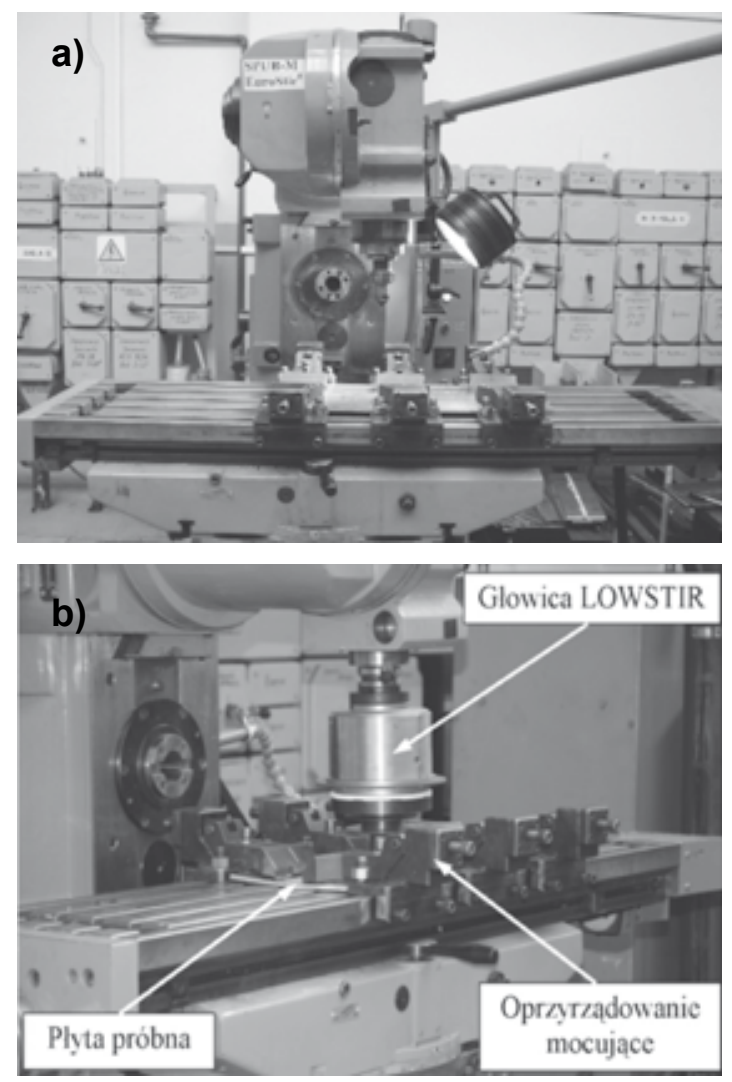

Rys. 1. Stanowisko badawcze do zgrzewania liniowego metodą FSW zbudowane na bazie konwencjonalnej frezarki: a) frezarka pionowa z głowicą dwuskrętną FYF32JU2, b) oprzyrządowanie zgrzewarki: uchwyty mocujące zgrzewane elementy i głowica Lowstir

Fig. 1. The test stand for Friction Stir Welding: a) conventional vertical milling machine FYF32JU2, b) tooling and Lowstir device for forces and torque measurements

aluminium przerabianego plastycznie EN AW-2017A. Skład chemiczny i właściwości fizyczne materiałów stosowanych w badaniach zestawiono w tablicach I i II.

$\mathrm{Z}$ blach $\mathrm{z}$ aluminium przerabianego plastycznie i z odlanych płyt przygotowano płyty próbne o wymiarach 500x100x6 mm. Płyty próbne unieruchamiano na stole roboczym zgrzewarki, dostawiając do czoła płytę $z$ aluminium odlewniczego do płyty z aluminium przerabianego plastycznie. W tych warunkach prowadzono badania wpływu procesu FSW na uplastycznianie obszaru zgrzewania materiałów znacznie różniących się

Tablica I. Skład chemiczny stopów aluminium zastosowanych w badaniach [6, 7]

Table I. Chemical composition of aluminium alloys used during studies $[6,7]$

\begin{tabular}{|c|c|c|c|c|c|c|c|c|c|c|}
\hline \multicolumn{2}{|c|}{ Oznaczenie stopu } & \multicolumn{9}{|c|}{ Zawartość pierwiastków, \% wag. } \\
\hline numeryczne & $\begin{array}{l}\text { symbolami } \\
\text { chemicznymi }\end{array}$ & $\mathrm{Si}$ & $\mathrm{Cu}$ & $\mathrm{Mg}$ & $\mathrm{Mn}$ & $\mathrm{Fe}$ & $\mathrm{Ti}$ & $\mathrm{Zn}$ & $\mathrm{Ni}$ & $\mathrm{Al}$ \\
\hline $\begin{array}{l}\text { EN AC-43200 } \\
(A K 9)^{*}\end{array}$ & $\begin{array}{c}\text { EN AC-Al } \\
\text { Si10Mg(Cu) }\end{array}$ & $\begin{array}{c}9,00 \\
\div 11,00\end{array}$ & 0,35 & $\begin{array}{c}0,20 \\
\div 0,45\end{array}$ & 0,55 & 0,65 & 0,20 & 0,35 & 0,15 & reszta \\
\hline $\begin{array}{l}\text { EN AW-2017A } \\
(\text { PA6 })^{* *}\end{array}$ & $\begin{array}{l}\text { EN AW-Al } \\
\text { Cu4MgSi }\end{array}$ & $\begin{array}{c}0,20 \\
\div 0,80\end{array}$ & $\begin{array}{c}3,50 \\
\div 4,50\end{array}$ & $\begin{array}{c}0,40 \\
\div 1,00\end{array}$ & $\begin{array}{c}0,40 \\
\div 1,00\end{array}$ & 0,70 & 0,15 & 0,25 & - & reszta \\
\hline \multicolumn{11}{|c|}{$\begin{array}{l}\text { Uwagi: } \\
\text { * Odlewniczy stop aluminium } \\
{ }^{* *} \text { Stop aluminium przerobiony plastycznie }\end{array}$} \\
\hline
\end{tabular}


Tablica II. Wybrane właściwości stopów aluminium zastosowanych w badaniach [6, 8]

Table II. Selected properties of aluminium alloys used during studies $[6,8]$

\begin{tabular}{|c|c|c|c|c|c|}
\hline \multicolumn{2}{|c|}{ Oznaczenie stopu } & \multicolumn{4}{c|}{ Minimalne właściwości } \\
\hline numeryczne & symbolami chemicznymi & $\mathrm{R}_{\mathrm{p} 0,2}, \mathrm{MPa}$ & $\mathrm{R}_{\mathrm{m}}, \mathrm{MPa}$ & $\mathrm{A}_{50 \mathrm{~mm}}, \%$ & $\mathrm{HB}$ \\
\hline EN AC-43200,(AK9)* & EN AC-Al Si10Mg(Cu) & 90 & 180 & 1 & 55 \\
\hline EN AW-2017A,(PA6)** & EN AW-Al Cu4MgSi & $\leq 145$ & $\leq 225$ & $\geq 13$ & 55 \\
\hline $\begin{array}{l}\text { Uwagi: } \\
\text { * Odlewniczy stop aluminium } \\
* * \text { Stop aluminium przerobiony plastycznie }\end{array}$
\end{tabular}

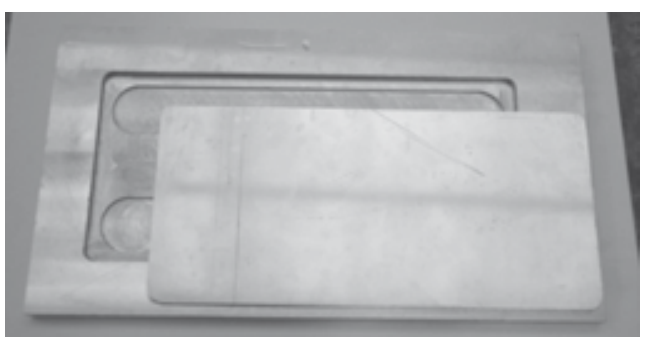

Rys. 2. Modelowa chłodnica. Pokrywa - stop EN AW-2017A. Odlewany korpus - stop EN AC-43200

Fig. 2. Model radiator. Cover plate - EN AW-2017A alloy. Casting frame - EN AC-43200 alloy

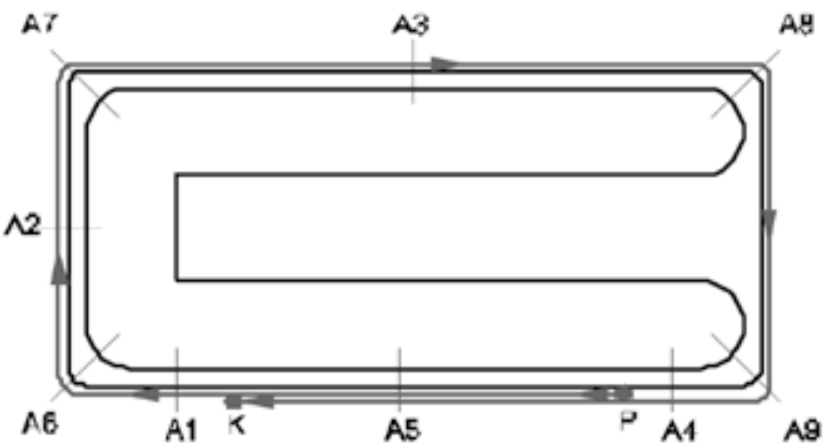

Rys. 3. Modelowa chłodnica. Kierunek zgrzewania oraz miejsca badań struktury

Fig. 3. Model radiator. Welding direction and places of micro and macroscopic examination

właściwościami fizycznymi, w szczególności badano wpływ kąta ustawienia narzędzia na formowanie się zgrzeiny, wpływ parametrów procesu i kształtu narzędzia na temperaturę i strukturę zgrzein oraz na jakość zgrzewania.

W następnej kolejności przygotowano modelową chłodnicę składającą się z odlewanego korpusu i pokrywy wykonanej z aluminium przerabianego plastycznie (rys. 2). Kierunek zgrzewania oraz miejsca badań struktury chłodnicy przedstawiono na rysunku 3.

\section{Narzędzia do zgrzewania}

W trakcie pracy przebadano wpływ szeregu narzędzi, o różnym kształcie i wymiarach części roboczych, na jakość zgrzewania prowadzonego w różnej konfiguracji ustawienia zgrzewanych elementów. Narzędzia wykonano ze stali szybkotnącej HS 6-5-2 (SW7M) [9]. Wymiary narzędzi stosowanych $\mathrm{w}$ badaniach zestawiono w tablicy III.

\section{Badania sił i momentu tarcia}

Na stanowisku wyposażonym w przyrząd Lowstir badano wpływ parametrów procesu na siły i moment siły oddziałujące na narzędzie. Wyniki przykładowego pomiaru parametrów mechanicznych przedstawiono na rysunku 4 . Wyniki badań zestawiono w tablicy IV. Obliczenia poszczególnych zależności dokonywano dla stanu ustalonego, przy ustabilizowanych warunkach nagrzewania i rozchodzenia się ciepła podczas zgrzewania.

Przeprowadzono badania dla narzędzi przedstawionych w tablicy III. Poszczególne wartości sił nieco się różniły, lecz ogólne zależności wpływu warunków zgrzewania na ich wartości były bardzo podobne. W tablicy IV przytoczono wyniki badań przeprowadzonych dla narzędzia $S(1)$, natomiast w sposób zbiorczy zależność momentu tarcia, siły w kierunku zgrzewania $\left(F_{x}\right)$ i siły docisku $\left(F_{y}\right)$ od prędkości zgrzewania i prędkości obrotowej dla przykładowego narzędzia S (2) przedstawiono na rysunku 5.

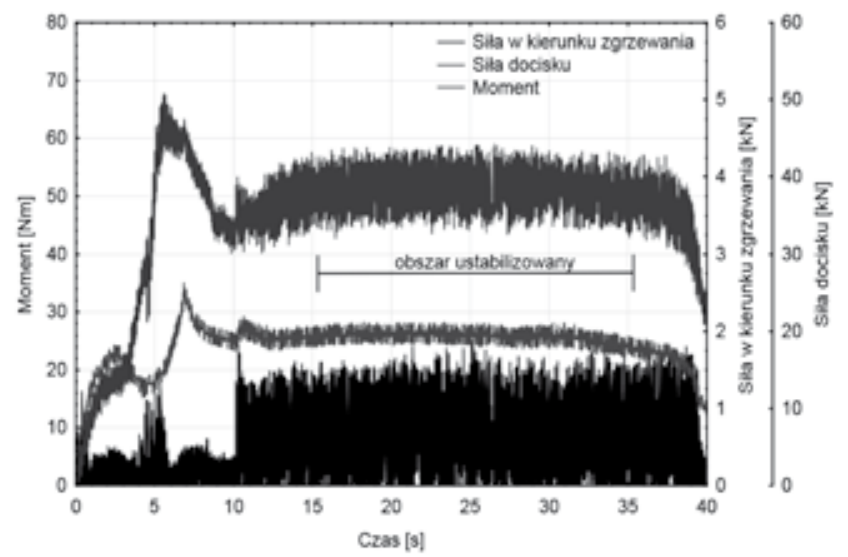

Rys. 4. Przebieg siły docisku $F_{z}$, momentu siły i siły $w$ kierunku zgrzewania $F_{x}$ rejestrowanych podczas badań wzdłuż całej linii zgrzewania

Fig. 4. Run of the $F_{z}$ and $F_{x}$ forces and torque measured during welding along the welding line 
Tablica. III. Narzędzia stosowane w badaniach

Table III. Tools used during studies

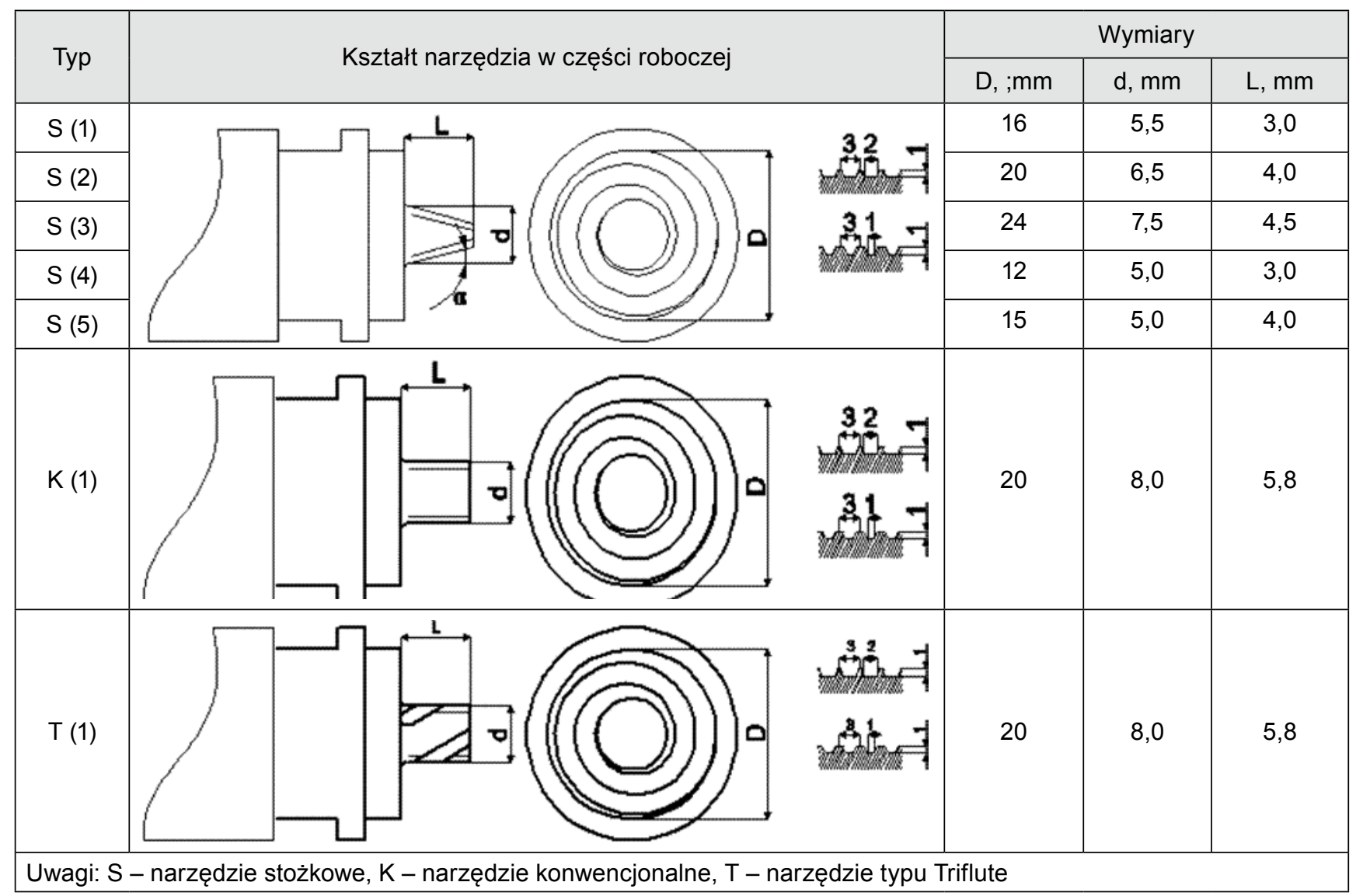

Tablica IV. Wyniki pomiarów sił i momentu siły w stanie ustalonym dla różnych warunków zgrzewania narzędziem S (1)

Table IV. Results of the measurements of forces and torque in steady state for a different welding conditions with the use of S (1) tool

\begin{tabular}{|c|c|c|c|c|c|c|}
\hline \multirow{2}{*}{$\begin{array}{c}\text { Materiał od strony } \\
\text { natarcia }\end{array}$} & \multicolumn{2}{|c|}{ Parametry ruchu narzędzia } & \multirow{2}{*}{$\begin{array}{c}\text { Moment } \mathrm{M}_{\mathrm{t}} \\
\mathrm{Nm}\end{array}$} & \multirow{2}{*}{$\underset{k N}{\text { Siła } F_{z}}$} & \multirow{2}{*}{$\underset{k N}{\text { Siła } F_{x}}$} & \multirow{2}{*}{ Uwagi } \\
\hline & $\begin{array}{c}\mathrm{V}_{\mathrm{n}} \\
\mathrm{obr} / \mathrm{min}\end{array}$ & $\frac{\mathrm{V}_{\mathrm{zg}}}{\mathrm{mm} / \mathrm{min}}$ & & & & \\
\hline EN AC-43200 & $560 /$ & 280 & 37,1 & 15,5 & 1,2 & kąt $1,5^{\circ}$ \\
\hline EN AC-43200 & 560 & 355 & 36,5 & 15,6 & 1,3 & kąt $1,5^{\circ}$ \\
\hline EN AC-43200 & 710 & 355 & 29,6 & 15,6 & 1,4 & kąt $1,5^{\circ}$ \\
\hline EN AW-2017A & 560 & 280 & 35,8 & 15,6 & 0,7 & kąt $1,5^{\circ}$ \\
\hline EN AW-2017A & 560 & 355 & 34,5 & 14,8 & 0,6 & kąt $1,5^{\circ}$ \\
\hline EN AW-2017A & 710 & 355 & 28,3 & 14,4 & 1,4 & kąt $1,5^{\circ}$ \\
\hline EN AW-2017A & 560 & 280 & 32,1 & 10,0 & 1,1 & kąt $0^{\circ}$ \\
\hline EN AW-2017A & 560 & 355 & 32,4 & 9,9 & 1,0 & kąt $0^{\circ}$ \\
\hline EN AW-2017A & 710 & 355 & 26,8 & 10,5 & 1,2 & kąt $0^{\circ}$ \\
\hline EN AC-43200 & 560 & 355 & 36,2 & 12,7 & 1,5 & kąt $0^{\circ}$ \\
\hline EN AC-43200 & 710 & 355 & 26,2 & 10,7 & 1,4 & kąt $0^{\circ}$ \\
\hline
\end{tabular}




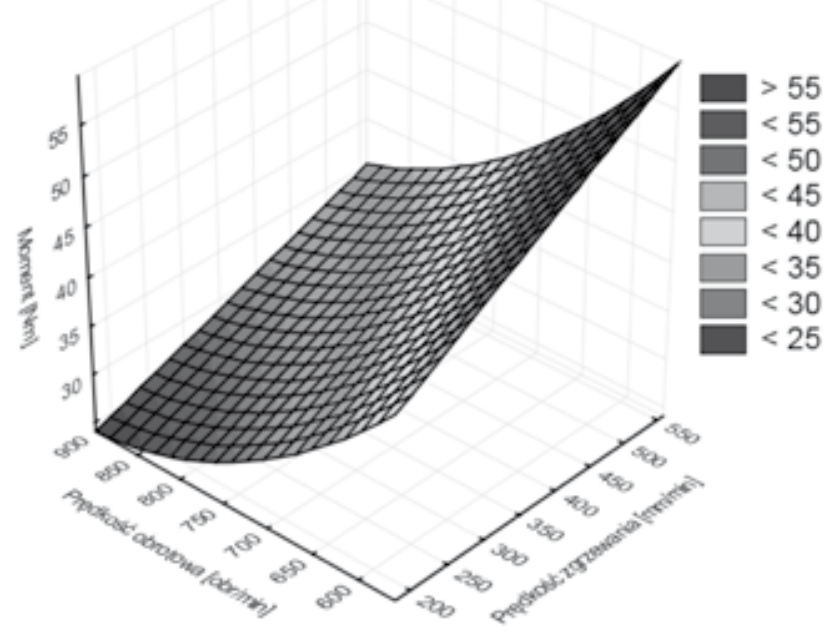

Rys. 5. Wpływ prędkości obrotowej $V_{n}$ i zgrzewania $V_{z g}$ na moment $M_{t}$ działający na narzędzie $S(2)$

Fig. 5. Influence of the rotation speed $V_{n}$ and travel speed $V_{z g}$ on the torque affected on S (2) tool

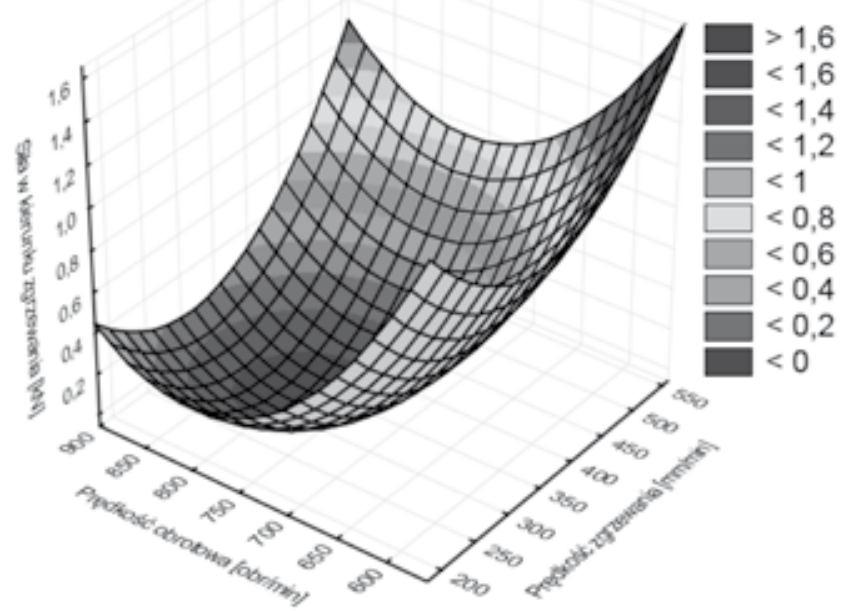

Rys. 6. Wpływ prędkości obrotowej $V_{n}$ i zgrzewania $V_{z g}$ na siłę $F_{x}$ działającą na narzędzie $S(2)$

Fig. 6. Influence of the rotation speed $V_{n}$ and travel speed $V_{z g}$ on the $F_{x}$ force affected on $S(2)$ tool

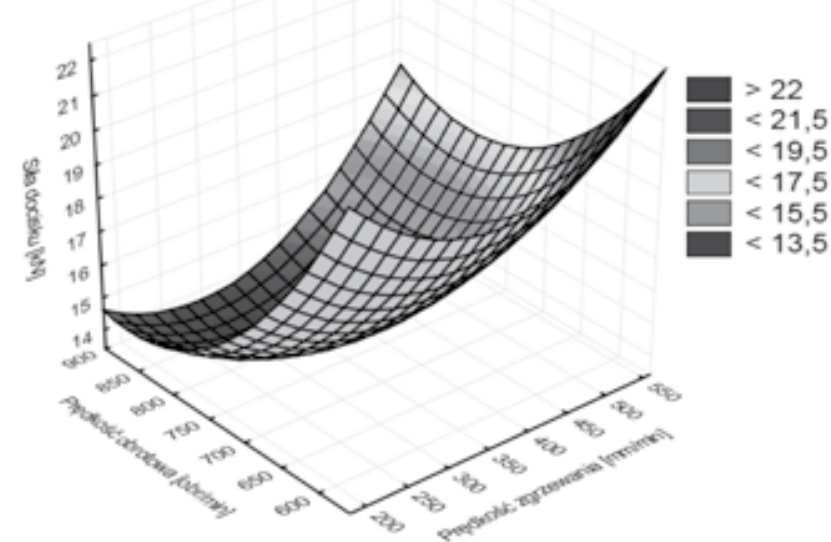

Rys. 7. Wpływ prędkości obrotowej $V_{n}$ i zgrzewania $V_{z g}$ na siłę $F_{z}$ działającą na narzędzie $S(2)$

Fig. 7. Influence of the rotation speed $V_{n}$ and travel speed $V_{z g}$ on the $F_{z}$ force affected on $S(2)$ tool

\section{Badanie wpływu narzędzia na jakość zgrzewania}

Badania wpływu wymiaru narzędzia na jakość zgrzewania FSW prowadzono z użyciem czterech różnych narzędzi przy różnych parametrach zgrzewania. Kształty i wymiary narzędzi zestawiono w tablicy III. Wybrane zestawy parametrów, stosowanych w badaniach, przedstawiono $w$ tablicy $\mathrm{V}$.

$W$ badaniach analizowano proces formowania się lica zgrzeiny, wielkość wypływek, jakość powierzchni oraz strukture zgrzein na przekrojach złączy. Przykładowe powierzchnie zgrzein przedstawiono na rysunkach 8 i 9 . Typowe makrostruktury zgrzein pokazano na rysunkach $10 \div 16$, a wybrane struktury zgrzein w badaniach mikroskopowych na rysunkach $17 \div 19$.

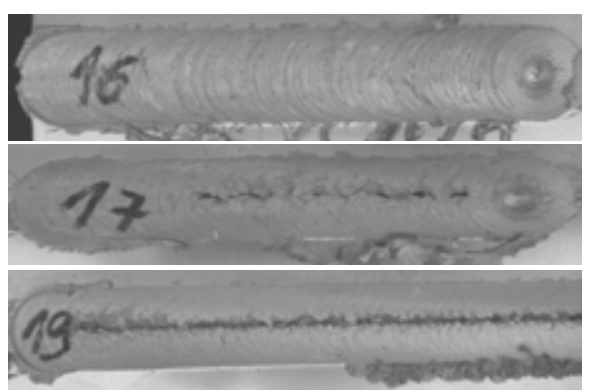

EN AC-43200 od strony natarcia

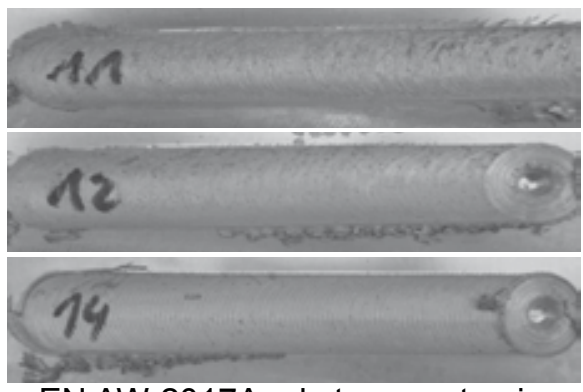

EN AW-2017A od strony natarcia

Rys. 8. Powierzchnie zgrzein wykonanych narzędziem $S$ (2)

Fig. 8. View of the surfaces of the welds made with the use $S(2)$ tool

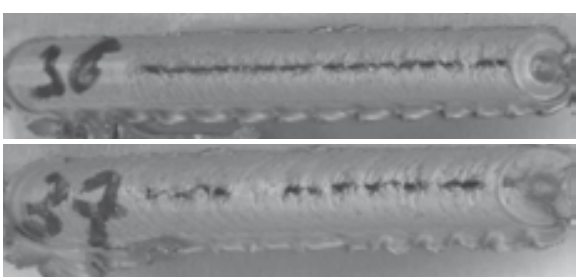

EN AC-43200 od strony natarcia

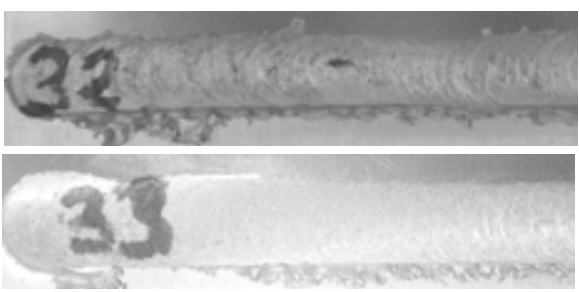

EN AW-2017A od strony natarcia

Rys. 9. Powierzchnie zgrzein wykonanych narzędziem S (4)

Fig. 9. View of the surfaces of the welds made with the use $S(4)$ tool 
Tablica V. Parametry zgrzewania

Table V. Welding parameters

\begin{tabular}{|c|c|c|c|c|c|}
\hline \multirow{2}{*}{$\begin{array}{c}\mathrm{Nr} \\
\text { parametru }\end{array}$} & \multirow{2}{*}{$\begin{array}{c}\text { Typ } \\
\text { narzędzia } \\
\text { (nr) }\end{array}$} & \multirow{2}{*}{$\begin{array}{c}\text { Materiał od strony } \\
\text { natarcia }\end{array}$} & \multicolumn{2}{|c|}{ Parametry ruchu narzędzia } & \multirow{2}{*}{ Uwagi } \\
\hline & & & $\begin{array}{c}\mathrm{V}_{\mathrm{n}} \\
\mathrm{obr} / \mathrm{min}\end{array}$ & $\mathrm{V}_{\mathrm{zg}} \mathrm{mm} / \mathrm{min}$ & \\
\hline 1 & $S(1)$ & EN AC-43200 & 560 & 280 & $\begin{array}{c}\text { Poprawne lico } \\
\text { Liniowa nieciągłość }\end{array}$ \\
\hline 3 & $S(1)$ & EN AC-43200 & 900 & 180 & Poprawne lico i budowa zgrzeiny \\
\hline 5 & $S(1)$ & EN AC-43200 & 900 & 560 & $\begin{array}{l}\text { Poprawne lico } \\
\text { Drobna nieciągłość }\end{array}$ \\
\hline 6 & $S(1)$ & EN AW-2017A & 560 & 280 & $\begin{array}{c}\text { Poprawne lico } \\
\text { Liniowa nieciągłość }\end{array}$ \\
\hline 7 & $S(1)$ & EN AW-2017A & 450 & 180 & $\begin{array}{c}\text { Poprawne lico i budowa zgrzeiny Bardzo } \\
\text { drobne wady }\end{array}$ \\
\hline 8 & $S(1)$ & EN AW-2017A & 900 & 180 & $\begin{array}{l}\text { Nierówna powierzchnia lica } \\
\text { Bardzo drobne wady }\end{array}$ \\
\hline 9 & $S(1)$ & EN AW-2017A & 450 & 560 & $\begin{array}{c}\text { Poprawne lico i budowa zgrzeiny } \\
\text { Bardzo drobne wady }\end{array}$ \\
\hline 10 & $S(1)$ & EN AW-2017A & 900 & 560 & $\begin{array}{c}\text { Poprawne lico } \\
\text { Liniowa nieciągłość }\end{array}$ \\
\hline 11 & $S(2)$ & EN AW-2017A & 560 & 280 & Nierówna powierzchnia lica \\
\hline 15 & $S(2)$ & EN AW-2017A & 900 & 560 & $\begin{array}{c}\text { Poprawne lico } \\
\text { Liniowa nieciągłość }\end{array}$ \\
\hline 23 & $S(3)$ & EN AC-43200 & 900 & 180 & Poprawne lico i budowa zgrzeiny \\
\hline 27 & $S(3)$ & EN AW-2017A & 450 & 180 & Poprawne lico i budowa zgrzeiny \\
\hline 28 & $S(3)$ & EN AW-2017A & 900 & 180 & $\begin{array}{l}\text { Nierówna powierzchnia lica } \\
\text { Pustka kanalikowa }\end{array}$ \\
\hline 33 & $S(4)$ & EN AW-2017A & 900 & 180 & Poprawne lico i budowa zgrzeiny \\
\hline 40 & $S(4)$ & EN AC-43200 & 900 & 560 & $\begin{array}{c}\text { Nieprawidłowe mieszanie materiału jądra. } \\
\text { Duża pustka kanalikowa }\end{array}$ \\
\hline
\end{tabular}

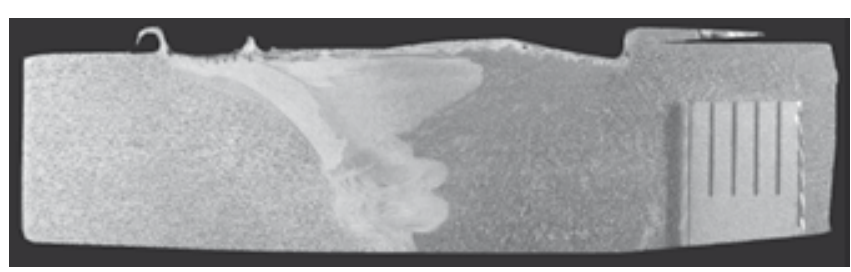

Rys. 10. Makrostruktura zgrzeiny FSW. Materiał EN AW-2017A od strony natarcia. Parametry zgrzewania: $\mathrm{nr} 11 \mathrm{z}$ tabl. V

Fig. 10. Macrostructure of FSW weld. EN AW-2017A by the advancing side. Welding parameters: no 11 from table $\mathrm{V}$

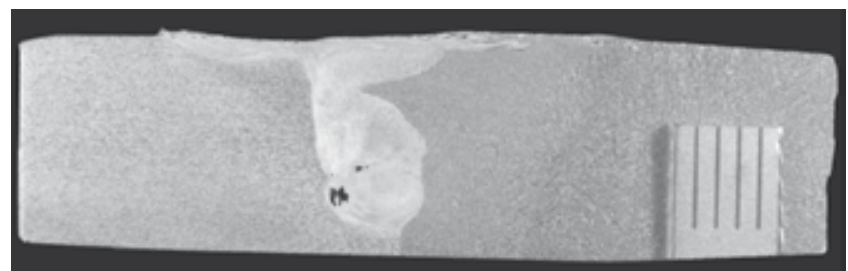

Rys. 11. Makrostruktura zgrzeiny FSW. Materiał EN AW-2017A od strony natarcia. Parametry zgrzewania: $\mathrm{nr} 15 \mathrm{z}$ tabl. V

Fig. 11. Macrostructure of FSW weld. EN AW-2017A by the advancing side. Welding parameters: no 15 from table $\mathrm{V}$

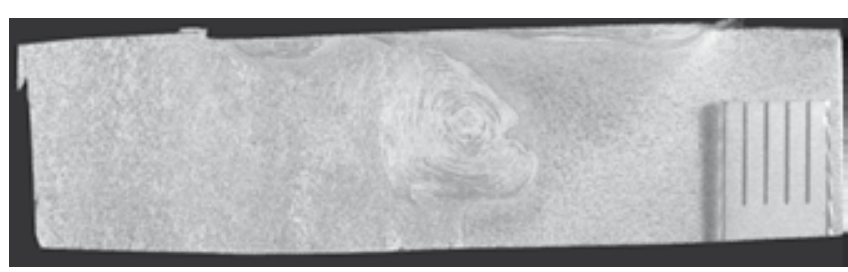

Rys. 12. Makrostruktura zgrzeiny FSW. Materiał EN AC-43200 od strony natarcia. Parametry zgrzewania: $\mathrm{nr} 23 \mathrm{z}$ tabl. V

Fig. 12. Macrostructure of FSW weld. EN AC-43200 by the advancing side. Welding parameters: no 23 from table $\mathrm{V}$

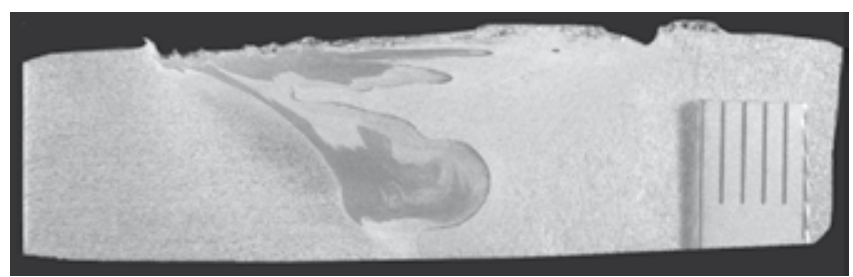

Rys. 13. Makrostruktura zgrzeiny FSW. Materiał EN AW-2017A od strony natarcia. Parametry zgrzewania: $\mathrm{nr} 27 \mathrm{z}$ tabl. V

Fig. 13. Macrostructure of FSW weld. EN AW-2017A by the advancing side. Welding parameters: no 27 from table $V$ 


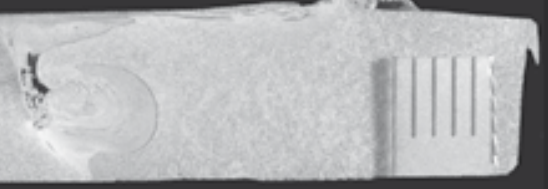

Rys. 14. Makrostruktura zgrzeiny FSW. Materiał EN AW-2017A od strony natarcia. Parametry zgrzewania: $\mathrm{nr} 28 \mathrm{z}$ tabl. V

Fig. 14. Macrostructure of FSW weld. EN AW-2017A by the advancing side. Welding parameters: no 28 from table $\mathrm{V}$

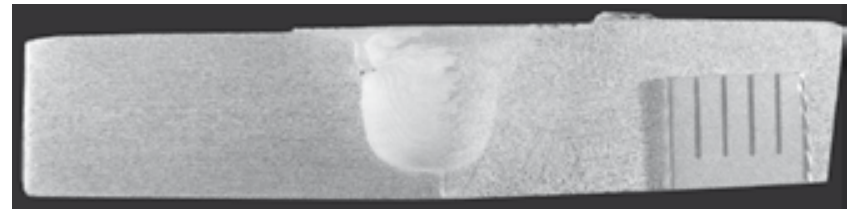

Rys. 15. Makrostruktura zgrzeiny FSW. Materiał EN AW-2017A od strony natarcia. Parametry zgrzewania: $\mathrm{nr} 33 \mathrm{z}$ tabl. V

Fig. 15. Macrostructure of FSW weld. EN AW-2017A by the advancing side. Welding parameters: no 33 from table $\mathrm{V}$

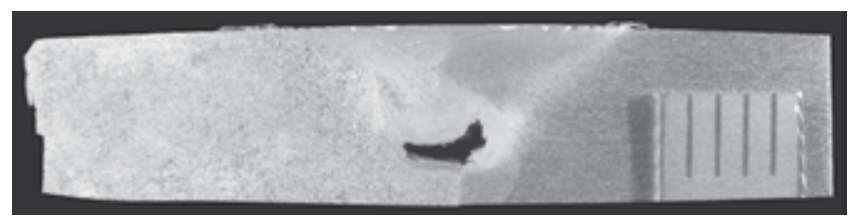

Rys. 16. Makrostruktura zgrzeiny FSW. Materiał EN AC-43200 od strony natarcia. Parametry zgrzewania: $\mathrm{nr} 40 \mathrm{z}$ tabl. V

Fig. 16. Macrostructure of FSW weld. EN AC- 43200 by the advancing side. Welding parameters: no 40 from table $\mathrm{V}$

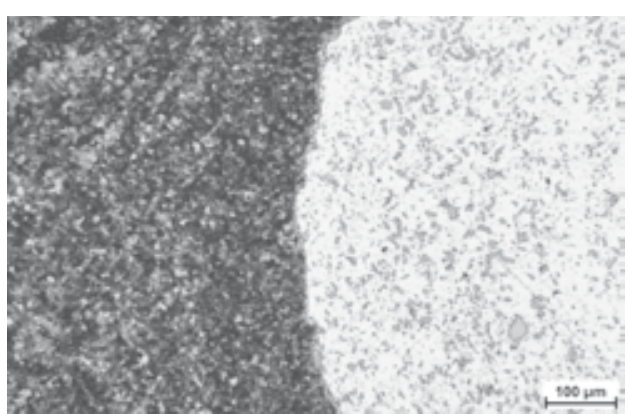

Rys. 17. Mikrostruktura fragmentu zgrzeiny FSW. Materiał EN AC-43200 od strony natarcia. Parametry zgrzewania: $\mathrm{nr} 3 \mathrm{z}$ tabl. V. Przejście pomiędzy materiałem zgrzeiny a SWC od strony natarcia. Traw. odcz. Kellera Fig. 17. Microstucture of FSW weld. EN AC-43200 by the advancing side. Welding parameters: no 3 from table $V$. Boundary between the weld and HAZ from the advancing side. Etching Keller

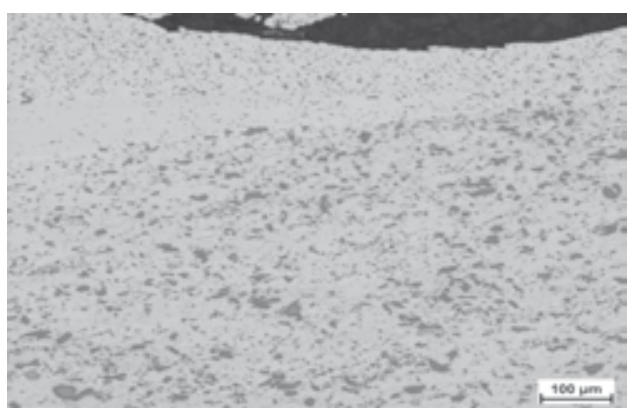

Rys. 18. Mikrostruktura fragmentu zgrzeiny FSW. Materiał EN AC43200 od strony natarcia. Parametry zgrzewania: $\mathrm{nr} 3$ z tabl. V. Struktura pod licem $w$ centralnym obszarze zgrzeiny. Traw. odcz. Kellera Fig. 18. Microstructure of FSW weld. EN AC-43200 by the advancing side. Welding parameters: no 3 from table V. Structure under the face of weld in the central area of the weld. Etching Keller

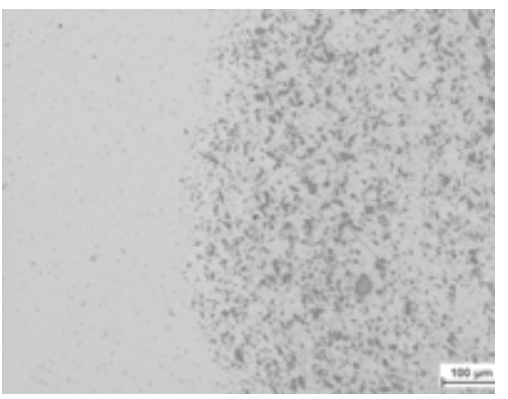

Rys. 19. Mikrostruktura fragmentu zgrzeiny FSW. Materiał EN AC-43200 od strony natarcia. Parametry zgrzewania: $\mathrm{nr} 3 \mathrm{z}$ tabl. V. Przejście pomiędzy materiałem zgrzeiny a materiałem rodzimym od strony spływu. Traw. Keller

Fig. 19. Microstucture of FSW weld. EN AC- 43200 by the advancing side. Welding parameters: no 3 from table $V$. Boundary between the weld and parent material from the retreating side. Etching Keller

\section{Badania zgrzewania FSW modelowej chłodnicy}

Badania procesu zgrzewania elementów modelowej chłodnicy prowadzono na podstawie o doświadczeń wynikające $z$ badań procesu tworzenia złączy przy zgrzewaniu płyt.

W wyniku prób i badań dobrano wymiary narzędzia, prędkość zgrzewania i sposób mocowania elementów chłodnicy. Z modelowej chłodnicy wycięto próbki do badań struktury zgrzeiny $w$ newralgicznych miejscach złącza. Miejsce pobrania próbek przedstawiono na rysunku 3. Charakterystyczne struktury zgrzein w wybranych obszarach przedstawiono na rysunkach $20 \div 23$.

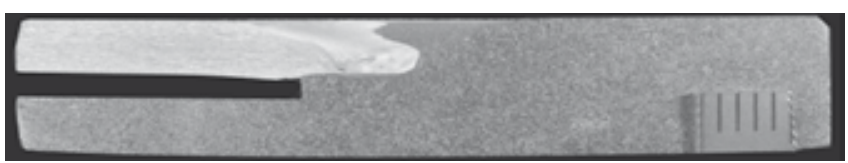

Rys. 20. Makrostruktura zgrzeiny FSW w miejscu A2 z rys. 3

Fig. 20. Macrostructure of FSW weld in the point A2 from Fig. 3

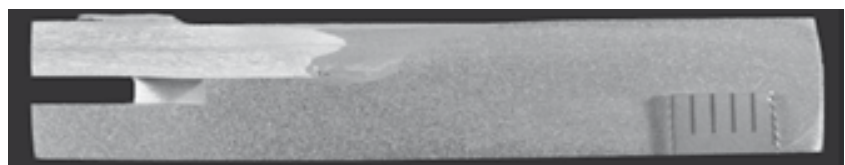

Rys. 21. Makrostruktura zgrzeiny FSW w miejscu A6 z rys. 3

Fig. 21. Macrostructure of FSW weld in the point $A 6$ from Fig. 3

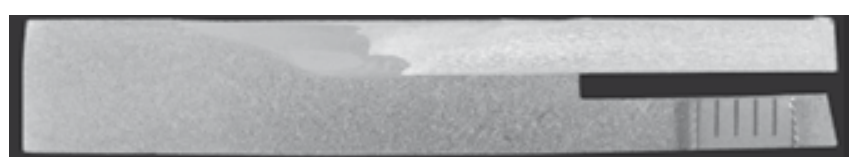

Rys. 22. Makrostruktura zgrzeiny FSW w miejscu A9 z rys. 3

Fig. 22. Macrostructure of FSW weld in the $A 9$ point from Fig. 3

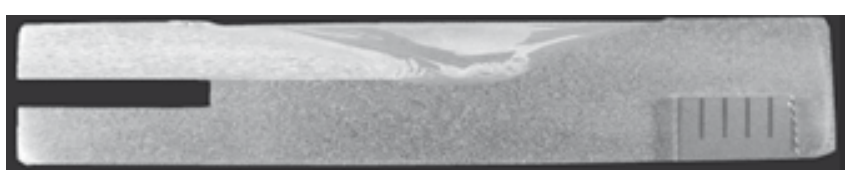

Rys. 23. Makrostruktura zgrzeiny FSW $w$ miejscu A9 z rys. 3 - w przypadku ustawienia stopu EN AW-2017A od strony spływu

Fig. 23. Macrostructure of FSW weld in the point A9 from Fig. 3. EN AW-2017A by the retreating side 


\section{Badania właściwości mechanicznych}

Badania właściwości mechanicznych złączy modelowej chłodnicy wykonano na podstawie badań twardości zgrzein oraz próby ciśnieniowej całej chłodnicy. Zwykle tego typu urządzenia pracują przy ciśnieniu roboczym

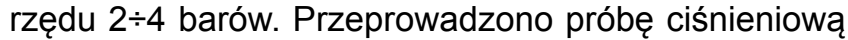
przy ciśnieniu 6 barów sieci pneumatycznej. W wyniku prób stwierdzono, że żadna z badanych chłodnic nie uległa zniszczeniu ani odkształceniu i wszystkie były szczelne przy ciśnieniu próbnym 6 barów.

Sprawdzono profil twardości wybranych zgrzein wyciętych z chłodnic poddanych badaniom metalograficznym. Twardość stopu przerobionego plastycznie wynosi ok. $71 \mathrm{HV}$, natomiast stop odlewniczy charakteryzuje się twardością ok. $60 \mathrm{HV}$. Na rysunku 24 przedstawiono mapę twardości próbki wyciętej z chłodnicy zgrzewanej przy ustawieniu stopu EN AC-43200 od strony natarcia. Otrzymano podobny rozkład twardości dla próbki pobranej z chłodnicy zgrzewanej przy podobnym ustawieniu stopu EN AW-2017A.

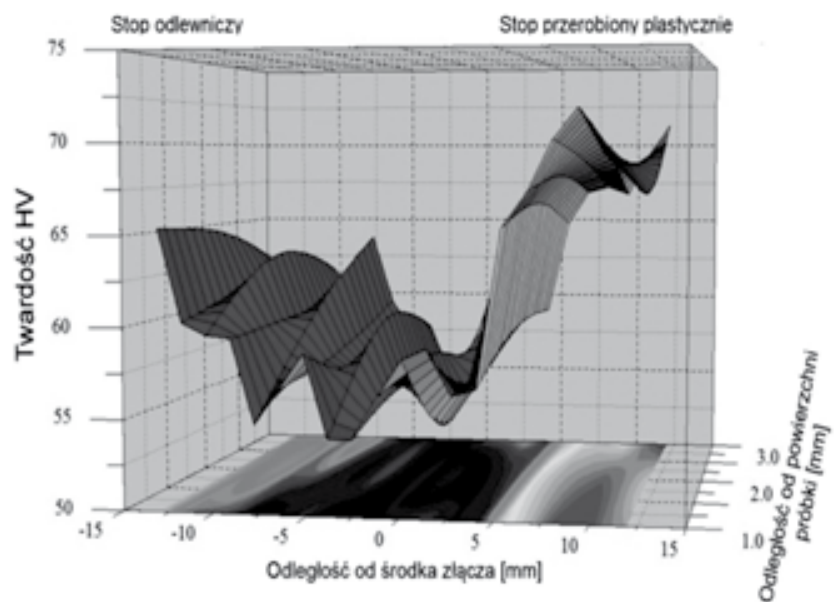

Rys. 24. Mapa twardości obszaru złącza dla próbki wyciętej z chłodnicy zgrzewanej przy ustawieniu stopu EN AC-43200 od strony natarcia Fig. 24. Hardness map of the welding area of joint for sample cutted from the radiator. EN AC-43200 by the advancing side

\section{Analiza wyników}

Badania wykazały, że kąt ustawienia narzędzia ma istotne znaczenie $\mathrm{w}$ aspekcie sił związanych $\mathrm{z}$ procesem zgrzewania, natomiast na jakość zgrzewania duży wpływ wywiera ustawienie elementów. Łatwiej również uzyskać zwartą strukturę zgrzeiny podczas zgrzewania z narzędziem nachylonym pod niewielkim kątem, niż w przypadku prostopadłego ustawienia narzędzia. W przypadku nachylenia narzędzia moc cieplna procesu jest większa (siła docisku i moment tarcia są wyższe) i większa jest ilość ciepła generowana w styku tarciowym. Ułatwia to formowanie materiału zgrzeiny, zwiększa jednak siły działające na narzędzie, co może wpływać na jego trwałość.
W przypadku ustawienia stopu przerabianego plastycznie EN AW-2017A od strony natarcia znacznie częściej występowały wady struktury w postaci kanalikowych nieciągłości w obszarze końcówki oddziaływania narzędzia, niż w przypadku ustawienia stopu odlewniczego od drugiej strony. Ta tendencja jest szczególnie widoczna przy zgrzewaniu bez kąta pochylenia narzędzia. Podobne wyniki uzyskano w pracy [10].

Aby jakość zgrzewania była zadowalająca, prędkość obrotowa nie może być zbyt duża. Przy prędkości obrotowej $900 \mathrm{obr} / \mathrm{min}$, nawet przy ustawieniu stopu odlewniczego od strony natarcia, w obszarze oddziaływania jego końcówki występują nieciągłości (np. rys. 11, 14).

Z badań wpływu wymiarów narzędzia z trzpieniem stożkowym i parametrów jego ruchu na jakość procesu zgrzewania wynika, że pewne warunki zgrzewania wpływają na jakość lica zgrzeiny i formowania się górnych warstw złącza, inne z kolei mają decydujące znaczenie w procesie formowania się głębszych warstw zgrzeiny.

Formowanie lica zgrzeiny jest bardziej utrudnione w przypadku ustawienia stopu odlewniczego od strony natarcia. W tych samych warunkach zgrzewania (narzędzie i parametry takie same) lico zgrzeiny jest dobrze uformowane, gdy od strony natarcia jest stop EN AW-2017A, natomiast gdy jest tam stop odlewniczy EN AC-43200, występuje wyraźnie widoczna liniowa nieciągłość (np. rys. 8 i 9). Wada na powierzchni lica zgrzeiny występuje również w przypadku, gdy powierzchnia wieńca opory jest zbyt mała w stosunku do średnicy trzpienia narzędzia. Wraz ze zwiększaniem grubości zgrzewanych blach i płyt musi wzrastać średnica narzędzia, zarówno trzpienia, jak i wieńca opory.

Stwierdzono, że w obszarze oddziaływania końcówki narzędzia mogą występować nieciągłości, których wymiary i zakres występowania zależą głównie od parametrów ruchu narzędzia. Nieciągłości te ulokowane są przede wszystkim od strony natarcia i bardziej widoczne są w przypadku zgrzewania elementów ze stopu EN AW-2017A (np. rys. 11, 14), niż stopu odlewniczego (rys. 16). Wady te obserwowano również w pracy [11].

Zwiększanie prędkości zgrzewania również niekorzystnie wpływa na występowanie nieciągłości w tym obszarze. Przy bardzo wolnym procesie zgrzewania (rys. 13), nawet przy ustawieniu stopu EN AW-2017A od strony natarcia, wady nie występują lub są bardzo niewielkie. W przypadku takiego ustawienia stopu odlewniczego od strony natarcia można wykonywać zgrzeiny przy większych prędkościach posuwu narzędzia (np. przy parametrach nr 5, tabl. V). Podobnie stwierdzono w pracach [12] i [13].

Pozostałe strefy zgrzeiny były ciągłe i wykazywały bardzo dobre powiązanie pomiędzy poszczególnymi warstwami mieszanych partii materiałów (np. rys. 10, 15). W badaniach stwierdzono, że twardość obszaru mieszania zgrzeiny ulega obniżeniu. W pracach $[14,15]$ zauważono, że profil twardości złącza zależy od rodzaju zgrzewanego stopu i może również ulegać zwiększeniu w strefie mieszania. 
Badania zgrzewania prowadzone na zgrzeinach modelowej chłodnicy wykazały podobny wpływ warunków zgrzewania, jak w przypadku procesu prowadzonego na płytach próbnych. Przy prawidłowo dobranych warunkach zgrzewania struktura zgrzein jest zwarta na całej głębokości zgrzewania. Nie obserwowano wad w strukturze zgrzein uzyskanych przy zgrzewaniu w obu badanych przypadkach: zarówno przy ustawieniu stopu przerabianego plastycznie od strony natarcia, jak i spływu, struktura była poprawna (np. rys. 20). Poprawną strukturę wykazywały również zgrzeiny wycięte z naroży chłodnicy, tj. z miejsc zmiany kierunku zgrzewania (rys. 21).

\section{Wnioski}

Na podstawie badań i analizy wyników sformułowano następujące wnioski:

- Do łączenia elementów wykonanych z aluminium odlewniczego z elementami wykonanymi z aluminium przerabianym plastycznie można zastosować metodę FSW. Poprawnie dobrane warunki zgrzewania pozwolą na uzyskanie dobrego jakościowo złącza o wymaganych właściwościach wytrzymałościowych.

- W przypadku zgrzewania elementów wzdłuż skomplikowanej trajektorii linii łączenia można zastosować narzędzie z trzpieniem stożkowym, co gwarantuje właściwą budowę strukturalną zgrzeiny przy minimalnych obciążeniach wrzeciona zgrzewarki oraz oprzyrządowania mocującego zgrzewane elementy.

- Zmiany parametrów zgrzewania (wahania docisków, zmiana prędkości obrotowej lub prędkości zgrzewania) wpływają ma zmianę ilości wydzielanego ciepła oraz sposób mieszania metali obu stopów w strefie oddziaływania narzędzia.

- W strukturze zgrzeiny, głównie w obszarze oddziaływania końcówki narzędzia, mogą występo- wać nieciągłości, których wielkość i zakres występowania zależą głównie od parametrów ruchu narzędzia. Nieciągłości te ulokowane są przede wszystkim od strony natarcia i bardziej widoczne są w przypadku zgrzewania elementów przy ustawieniu od strony natarcia stopu EN AW-2017A, niż stopu odlewniczego.

- Zwiększanie prędkości zgrzewania niekorzystnie wpływa na strukturę zgrzeiny. Przy bardzo wolnym procesie zgrzewania $(180 \mathrm{~mm} / \mathrm{min})$ nawet przy ustawieniu stopu EN AW-2017A od strony natarcia wady nie występują lub są bardzo niewielkie. W przypadku ustawienia stopu odlewniczego od strony natarcia można wykonywać zgrzeiny przy większych wydajnościach procesu zgrzewania.

- W przypadku zgrzewania FSW wzrost prędkości obrotowej i prędkości zgrzewania powodują najpierw spadek siły w kierunku zgrzewania, a następnie jej wzrost. Ta charakterystyczna cecha procesu skłania do poszukiwania takich warunków zgrzewania, przy których zostanie uzyskana właściwa struktura zgrzeiny, a siła oddziałująca na cały układ będzie najmniejsza.

\section{Literatura}

[1] Thomas W. M.: Friction Stir Butt Welding. Int. Patent Application. PCT/GB92/02203.1991.

[2] Thomas W, M., Norris I.M., Staines D.G., Watts E.R.: Friction Stir Welding - Process Developments and Variant Techniques. The SME Summit 2005. Oconomowoc, Milwaukee, USA, August, 2005

[3] Miles M. P., Melton D. W., Nelson T. W., Formability of frictionstir-welded Dissimilar-Aluminum-Alloy Sheets, Metallurgical and materials transactions, nr 36A, s. 3335-3342, 2005.

[4] Venkateswaran P., Xu Z. H., Li X., Reynolds A. P.: Determination of mechanical properties of $\mathrm{Al} \mathrm{Mg}$ alloys dissimilar friction stir welded interface by indentation methods, , Journal of Materials Science, nr 44, str. 4140-4147, 2009.

[5] DebRoy T., Bhadeshia H.K.D.H.: Friction stir welding of dissimilar alloys - a perspective. Science and Technology of Welding and Joining 15 (2010) 266 - 270

[6] PN-EN 1706:2011P. Aluminium i stopy aluminium - Odlewy Skład chemiczny i właściwości mechaniczne.

[7] PN-EN 573-3:2010P. Aluminium i stopy aluminium - Skład chemiczny i rodzaje wyrobów przerobionych plastycznie - Część 3: Skład chemiczny i rodzaje wyrobów.

[8] Dobrzański L.: Podstawy nauki o materiałach i metaloznawstwo, WNT, Warszawa, 2002.
[9] PN-EN 10027-1:2007P. Systemy oznaczania stali - Część 1: Znaki stali.

[10] Lee W. B., Yeon Y. M., Jung S. B.: The joint properties of dissimilar formed $\mathrm{Al}$ alloys by friction stir welding according to the fixed location of materials, Scripta Materialia $\mathrm{nr} 49$, s. 423-428, 2003.

[11] Kim Y. G., Fujii H., Tsumura T., Komazaki T., Nakata K.: Three defect types in friction stir welding of aluminium die casting alloy, Materials Science and Enginnering, nr A 415, str. 250254, 2006.

[12] Lee W. B., Yeon Y. M., Jung S. B.: The improvement of mechanical properties of friction-stir-welded A356 Al alloy, Materials Science and Engineering nr A 355, s. 154-159, 2003.

[13] Kim Y. G., Fujii H., Tsumura T., Komazaki T., Nakata K.: Effect of welding parameters on microstructure in the stir zone of FSW joints of aluminium die casting alloy, Materials Letter, nr 60, s. 3830-3837, 2006.

[14] Rodriguez N. A., Almanza E., Alvarez C. J.: Study of friction stir welded A319 and A413 aluminum casting alloys, Journal of Materials Science, nr 40, s. 4307-4312, 2005.

[15] Uematsu Y., Tozaki Y., Tokaji K.: Fatigue behawior of dissimilar friction stir welds between cast and wrought aluminum alloys, Strength of Materials, nr 40-1, s. 138-141, 2008. 